\title{
E-Sourcing, E-Maintenance and Public Procurement Performance: A Case of Kericho County-Kenya
}

\author{
Geoffrey Rotich ${ }^{1}$, Muma Benard ${ }^{2}$, Elyjoy Micheni ${ }^{3}$ \\ ${ }^{1}$ Department of Entrepreneurship Technology Leadership and Management, Jomo Kenyatta University of Agriculture and Technology, Juja, \\ Kenya \\ ${ }^{2}$ Department of Accounting, Finance and Management Science, Egerton University, Nakuru, Kenya \\ ${ }^{3}$ Department of Management Science and Technology, Technical University of Kenya, Nairobi, Kenya
}

Email address:

Jeff33ke@gmail.com (G. Rotich), mumabenard@gmail.com (M. Benard), elyjoymicheni@gmail.com (E. Michemi)

\section{To cite this article:}

Geoffrey Rotich, Muma Benard, Elyjoy Micheni. E-Sourcing, E-Maintenance and Public Procurement Performance: A Case of Kericho County-Kenya. Science Research. Vol. 4, No. 2, 2016, pp. 37-42. doi: 10.11648/j.sr.20160402.13

Received: November 13, 2015; Accepted: November 26, 2015; Published: April 12, 2016

\begin{abstract}
This study intended to establish the relationship between e-sourcing and e-maintenance aspects of e-procurement and procurement performance of county governments in Kenya. Kericho County was used as case. The study looked at all the public procurement processes and practices conducted and related them with procurement performance. The target respondents were employees in Kericho County while employees in procurement, finance and accounts and IT departments were purposively selected to form the sample frame from which the respondents were derived. To achieve the aim of the study, two hypotheses were tested; $\mathrm{Ho}_{1}$ : E-Maintenance, Repair and Operations do not significantly affect Procurement Performance of county governments in Kenya and $\mathrm{Ho}_{2}$ : E- Sourcing does not significantly affect Procurement Performance of county governments in Kenya. Hypotheses testing were conducted through one tailed t-test at 0.05 significance level. The findings of the study revealed positive relationship between E-sourcing and procurement performance and E-maintenance and procurement performance respectively. It was therefore recommended that E-sourcing needed to be done at every procurement cycle and databases be created on online suppliers in order to make them more traceable and that the public organizations should recruit its own e-maintenance personnel in order to ensure that organizational system is fully functional and serviceable as required at all times. Research gaps were identified that could not be filled by this study and the study suggest that studies should be conducted to highlight change processes in the procurement systems, the key drivers of change in institutions and the role staff in implementation of new systems.
\end{abstract}

Keywords: E-Sourcing, E-Maintenance, Procurement Performance

\section{Introduction}

\subsection{Background}

According to Vaidya, Sajeev and Callender (2006), while public procurement is one of the core functions of the government, it had been and continues to be neglected by academicians and researchers. This had created a knowledge gap making it a challenge for governmental entities, policy-makers, and public procurement professionals to make decisions relating to adoption of new technologies and emerging procurement trends. EProcurement is one of the reforms that have been adopted by the government of Kenya to enhance public procurement operations. In ideal conditions, adoption of e-procurement is expected to bring sanity in the procurement operations, reduce costs and enhance efficiency. For many organizations, including public organizations, the objectives of adoption of e-procurement include: enhance efficiency, improved accountability and transparency and reduced costs. However, many organizations adopt e-procurement strategies without clear understanding on what to expect. To understand the concept of e-procurement and the associated benefits, a number of studies had been done. For instance, 
studies have been done on implementation of eprocurement, challenges of implementation of eprocurement and benefits of e procurement. Studies had also related e procurement with other variables like operational and overall organizational performance. A few studies had related e-procurement with procurement performance while none had studied such relationship in the county governments. Since the adoption of devolved system of government in Kenya in 2013, Kenyan public procurement has been devolved. Just like the national government, the county governments are implementing eprocurement. Since no study had been done to relate eprocurement and procurement performance of county governments, there existed a knowledge gap as to the relationship between e-procurement and procurement performance among county governments. Such gaps needed to be filled through research. This study intended to bridge this gap by investigating the effect of e procurement on procurement performance of county governments.

\subsection{Problem Statement}

Various authors have conducted research on eprocurement relating it with other variables like profitability, transparency, efficiency and performance. Studies that had looked at performance majorly concentrated on operational and economic performance. Most studies that have related aspects of e-procurement with performance aspects have established that eprocurement activities have positive relationship with organizational performance. Organizations that adopt eprocurement initiatives in their procurement operations enjoy improved performance. However, some studies also revealed that e-procurement activities in themselves cannot improve performance. They must be backed up by management support and employees acceptance. It is also important to note that implementation of e-procurement practices is a long term affair that must be given a strategic look. Every participant must be involved and they must understand their roles. Very few studies have been done to relate e-procurement activities with aspects of performance in the public sector. In Kenya, particularly after the government was devolved and the government started implementing e-procurement practices in public procurement, hardly any study has been conducted to relate e-procurement with procurement performance. This study intends to bridge the gap by studying the relationship between e-sourcing and e-maintenance and procurement performance in the county governments in Kenya.

\subsection{Research Objectives}

1) To assess the relationship between E-Maintenance and Procurement Performance of county governments in Kenya

2) To determine the relationship between E- Sourcing and Procurement Performance of county governments in Kenya

\section{Literature Review}

\subsection{Innovation Diffusion Theory}

Innovation diffusion theory categorize adopters of innovation into five categories; innovators, individuals who want to be the first to try the innovation, Early Adopters, people who represent opinion leaders, Early Majority individuals who need to see evidence that the innovation works before they can adopt it, Late Majority, skeptical individuals who only adopts an innovation after it has been tried by the majority and Laggards, individuals who are very skeptical of change and are the hardest group to involve in the innovation process. The figure below shows the five categories.

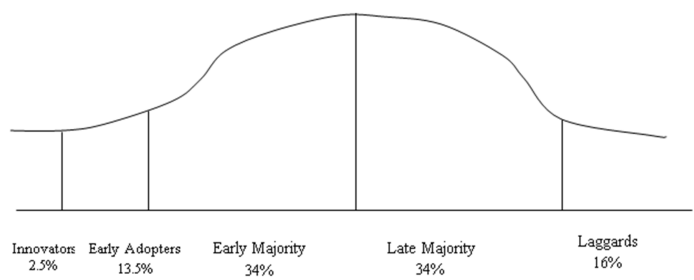

Source: Boston University School of Public Health (2013)

Figure 1. Categories of adopters.

According to innovation theory, rate of adoption of innovative strategies can be looked at in terms of; relative advantage given to the organization, compatibility, complexity, trial-ability of the new strategies and observability to the stakeholders within the social system. The second factor is communication that lays information and creating and sharing information relating to innovative initiatives in the organization. The third element is time that considers the duration involved in the innovation-decision process. The last element is the social context of the new systems (Rogers, 1997). Diffusion of innovation strategies requires evolution and reinvention of products and people so that they are able to perform better (Les Robinson, 2009). The concepts in this theory are very relevant to this study. They help build on the study and enable the researcher understand the expected relationship between the variables.

While innovation diffusion theory brings understanding of the innovation process, it has a number of limitations. The theory does not foster a participatory approach. It is therefore only able to work best with adoption of behaviors. Lastly, the theory does not take into account an organization's resources and social support in adoption of new methods.

\subsection{E-Sourcing}

Best Practice Network (2004) considers e- sourcing as a strategic process to establish, manage and monitor contracts and as an essential part of e-procurement. According to Aberdeen Group, reported by Best Practice Network (2004), a well-managed sourcing process should prioritize organizational requirements, understand supply market, select the supplier best placed in satisfying organizational needs, negotiate for the best overall value, establish and manage relationships with suppliers, develop cost reduction 
strategies and enhance long term performance of the purchasing operations and in turn the procurement performance. Aberdeen group developed a seven stages esourcing cycle that can be adopted in implementation of esourcing. Figure 2 shows the e-sourcing cycle. Lewis (2004) developed a guide for implementation of e-sourcing. In the guide, the first factor he emphasizes on configuration for capacity which involves understanding of the needs of the organization and developing a system take such needs. The second factor is an understanding that an e-sourcing platform will not automatically come with resource savings. Other actors he identified are selection of appropriate tools and development of the right skills is the third point he pointed. The organization need to train employees on the required skills and manage change in the work place.

\subsection{E-Maintenance}

E-maintenance is maintenance managed through computer over the internet (Levrat and Lund, 2003). United Nations (2011) points out that e-maintenance are one of the more effective and efficient tools of ensuring good governance in public procurement functions. It allows governments to apply standard procurement standards across the organization and its partners to enhance performance and efficiency in procurement functions. E-maintenance requires a software platform integrating with organization's tools to be managed (Levrat and Lund, 2003). Levrat and Lund (2003) classified the platforms into: software platforms that implement emaintenance software capabilities and software solution platform that support e-maintenance software capabilities. Implementing e-maintenance requires web services and collaboration principles to support proactivity in maintenance.

\subsection{Procurement Performance}

Table 1. Procurement Performance Indicators.

\begin{tabular}{|c|c|c|}
\hline Indicator & Description & $\begin{array}{l}\text { Performance } \\
\text { Category }\end{array}$ \\
\hline $\begin{array}{l}\text { Price } \\
\text { Variance }\end{array}$ & $\begin{array}{l}\text { Percentage price variance between } \\
\text { contract unit price and international unit } \\
\text { price for focus products }\end{array}$ & Cost \\
\hline $\begin{array}{l}\text { Contract } \\
\text { Utilization }\end{array}$ & $\begin{array}{l}\text { Percentage by value of purchases made } \\
\text { under simple purchase orders, annual } \\
\text { contracts, and multi-year contracts }\end{array}$ & Cost \\
\hline $\begin{array}{l}\text { Expiration } \\
\text { Management }\end{array}$ & Percentage number of expired products & Quantity \\
\hline $\begin{array}{l}\text { Supplier } \\
\text { Performance }\end{array}$ & $\begin{array}{l}\text { Percentage of orders in compliance with } \\
\text { contract criteria and Percentage of } \\
\text { orders delivered on time }\end{array}$ & Timeliness \\
\hline $\begin{array}{l}\text { Procurement } \\
\text { Cycle Time }\end{array}$ & $\begin{array}{l}\text { Percentage of procurements completed } \\
\text { (placed) within standard time guidelines }\end{array}$ & Timeliness \\
\hline $\begin{array}{l}\text { Payment } \\
\text { Processing } \\
\text { Time }\end{array}$ & $\begin{array}{l}\text { Percentage of supplier payments made } \\
\text { within the payment period called for in } \\
\text { the contract }\end{array}$ & Timeliness \\
\hline $\begin{array}{l}\text { Procurement } \\
\text { Cost }\end{array}$ & $\begin{array}{l}\text { Ratio of annual procurement unit cost- } \\
\text { to-value of annual purchases }\end{array}$ & $\begin{array}{l}\text { Systems } \\
\text { Productivity }\end{array}$ \\
\hline Staff Training & $\begin{array}{l}\text { Key training program components in } \\
\text { place and number of staff who receive } \\
\text { training annually }\end{array}$ & Quantity \\
\hline
\end{tabular}

Source: Expert Group Meeting (2001)
The concept of procurement performance has existed from as early as 1930s. Since then, attention from procurement practitioners, agencies and researchers has grown on the concept. While some scholars define procurement performance as a products of transparency, efficiency and effectiveness (Expert Group Meeting, 2001), others considers it as function of flexibility and enhanced effectiveness and efficiency of the procurement functions (Garran, 2005). USAID come up with indicators that can be used to measure procurement performance. Such indicators include: price variance, contract utilization, materials expiration management, supplier performance, procurement cycle time, payment processing time, emergency procurement, procurement cost, transparent tendering, staff training and transparent price information (USAID, 2013) Public procurement especially in developing countries faces challenges of not meeting the needs and expectations of the stakeholders. Different stakeholders have different expectations from the public procurement functions. There is therefore need to develop performance indicators for procurement functions.

Attention on procurement performance has generally increased from procurement practitioners, agencies and researchers (Kakwezi \& Nyeko, 2000). European Institute of Purchasing Management organized a conference in 2004 and identified intangible and financial indicators of procurement performance. Expert Group Meeting (2001) links procurement performance with transparency, efficiency and effectiveness. The performance indicators for procurement function can be categorized as presented in table 1 .

\subsection{Conceptual Framework}

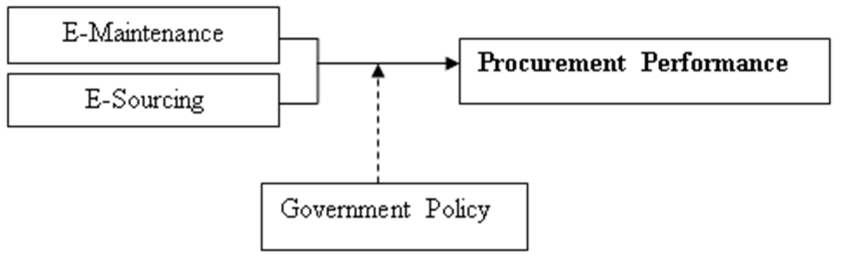

Figure 2. Conceptual Framework.

\section{Research Methodology}

This study adopted correlational, cross sectional research design and was a case study. The researcher settled for a case study because of the wide distribution of the study population that would make data collection difficult, especially with the limited time available for the research.

The target population constituted all employees in the county government of Kericho County which constituted 120 employees. All the 120 employees in the procurement finance and accounts and IT departments of Kericho County both at Management and non-management levels constituted the sample frame. From the sample frame, sample was determined using stratified random sampling. The following formula developed by Yamane (1967) was used.

$$
\mathrm{n}=\mathrm{N} /(1+\mathrm{N}(\mathrm{e} 2))
$$


Where; $\mathrm{n}=$ the desired sample size

$\mathrm{e}=$ probability of error (i.e., the desired precision, e.g., 0.05 for $95 \%$ confidence level).

$\mathrm{N}=$ the estimate of the population size.

Primary data was collected using structured questionnaires. Questionnaires were preferred because they are simple to administer, comprehensive and can be analyzed easily. The research questionnaires were developed and used in data collection. The questionnaires items were developed so as to collect data on each research indicator in line with specific research objectives. The questionnaires were administered by the researcher to all the respondents. The respondents were given time to fill the questionnaires after which they were collected for analysis.

To check on validity and reliability, Cronbach alpha coefficient was computed and compared with the threshold of 0.7. A content validity test was conducted to ensure all indicators measured are adequately represented. According to Kothari (2004), content validity is a function of whether the dimensions or elements of a concept have been captured.

The descriptive analysis was used to explain the aspects of e-sourcing, e-maintenance and procurement performance while correlation analysis was used to test the relationship between e-procurement and procurement performance. The research findings were presented using frequency and correlation tables accompanied with associated interpretation.

\section{Research Findings, Conclusions and Recommendations}

\subsection{Findings on E-Sourcing}

The responses were requested to express their opinion on e-sourcing. Questionnaire items were rated on a five point Likert scale ranging from; $1=$ strongly disagree to $5=$ strongly agree and the findings summarized in Table 1

\subsection{Findings on E-Maintenance}

The responses on e-maintenance items were rated on a five point Likert scale ranging from; $1=$ strongly disagree to $5=$ strongly agree and the findings summarized in Table 2 .

\subsection{Findings on Procurement Performance}

The responses on procurement performance were rated on a five point Likert scale ranging from; 1 = strongly disagree to $5=$ strongly agree. The respondents sentiments on procurement performance were as presented in table 3 .

Table 2. Findings on E-Sourcing.

\begin{tabular}{|c|c|c|c|c|c|}
\hline & SA & $\mathbf{A}$ & $\mathbf{N}$ & D & SD \\
\hline Statement & Freq $(\%)$ & Freq $(\%)$ & Freq $(\%)$ & Freq $(\%)$ & Freq (\%) \\
\hline $\begin{array}{l}\text { The county uses e-sourcing platform to improve search of prospective } \\
\text { suppliers to the county government. }\end{array}$ & $12(15)$ & $48(60)$ & $20(25.0)$ & 0 & 0 \\
\hline $\begin{array}{l}\text { The county adopts e-sourcing to get timely information about the offering of } \\
\text { different suppliers. }\end{array}$ & $11(13.8)$ & $48(60.0)$ & $21(26.3)$ & 0 & 0 \\
\hline $\begin{array}{l}\text { The county uses e-sourcing to reduce the costs associated sourcing of } \\
\text { materials, goods and services }\end{array}$ & $38(47.5)$ & $35(43.8)$ & $5(6.3)$ & $2(2.5)$ & 0 \\
\hline $\begin{array}{l}\text { The county uses e-sourcing to get adequate information possible when } \\
\text { selecting suppliers }\end{array}$ & $12(15.0)$ & $52(65.0)$ & $16(20.0)$ & 0 & 0 \\
\hline $\begin{array}{l}\text { The county uses e-sourcing to improve negotiation speed and value for all } \\
\text { purchases by the county government }\end{array}$ & $6(7.5)$ & $53(66.3)$ & $21(26.3)$ & 0 & 0 \\
\hline The county uses e-sourcing to improved strategic alliances with key suppliers & $30(37.5)$ & $5(6.3)$ & $10(12.5)$ & $31(38.8)$ & $4(5.0)$ \\
\hline
\end{tabular}

Table 3. Response on E-Maintance.

\begin{tabular}{|c|c|c|c|c|c|}
\hline & SA & A & $\mathbf{N}$ & D & SD \\
\hline Statement & Freq (\%) & Freq $(\%)$ & Freq (\%) & Freq (\%) & Freq $(\%)$ \\
\hline The county adopts e-maintenance to ensure timely contact firms providing repair services & $49(61.3)$ & $18(22.5)$ & $10(12.5)$ & $3(3.8)$ & 0 \\
\hline The county adopts e-maintenance to reduce stoppage in service delivery & $20(25.0)$ & 51(63.8) & $9(11.3)$ & 0 & 0 \\
\hline $\begin{array}{l}\text { The county adopts e-maintenance reduced considerably costs associated with maintenance } \\
\text { and repairs }\end{array}$ & 19(23.8) & $44(55.0)$ & $14(17.5)$ & $3(3.8)$ & 0 \\
\hline The county adopts e-maintenance to reduce the number of repair works and maintenance & 19(23.8) & $44(55.0)$ & 14(17.5) & $3(3.8)$ & 0 \\
\hline The county adopts e-maintenance to reduce system failure or breakdowns & $10(12.5)$ & 43(53.8) & $17(21.3)$ & $9(11.3)$ & $1(1.3)$ \\
\hline
\end{tabular}

Table 4. Response on Procurement Performance.

\begin{tabular}{|c|c|c|c|c|c|}
\hline & SA & A & $\mathbf{N}$ & D & SD \\
\hline Statement & Freq $(\%)$ & Freq $(\%)$ & Freq (\%) & Freq $(\%)$ & Freq $(\%)$ \\
\hline There is improved product compliance with order placed & 61(76.3) & 19(23.8) & 0 & 0 & 0 \\
\hline County experiences reduced inbound lead time & $34(42.5)$ & $44(55.0)$ & $2(2.5)$ & 0 & 0 \\
\hline County has achieved improved requirement specification for purchased materials & $48(60.0)$ & $30(37.5)$ & $2(2.5)$ & 0 & 0 \\
\hline County achieves timely submission of purchase requisitions by department for approval & $36(45.0)$ & $44(55.0)$ & 0 & 0 & 0 \\
\hline County achieves timely purchase requisition approval & $33(41.3)$ & $47(58.8)$ & 0 & 0 & 0 \\
\hline County achieves timely bidding process initiation and closure & $38(47.5)$ & $40(50.0)$ & $2(2.5)$ & 0 & 0 \\
\hline County achieves timely bids evaluation and supplier selection & $22(27.5)$ & $48(60.0)$ & $10(12.5)$ & 0 & 0 \\
\hline
\end{tabular}




\begin{tabular}{|c|c|c|c|c|c|}
\hline & SA & A & $\mathbf{N}$ & D & SD \\
\hline Statement & Freq $(\%)$ & Freq (\%) & Freq (\%) & Freq (\%) & Freq $(\%)$ \\
\hline County has reduced staff number involved in procurement & $10(12.5)$ & $43(53.8)$ & $17(21.3)$ & $9(11.3)$ & $1(1.3)$ \\
\hline County experiences increased procurement volumes processed & $32(40.0)$ & $38(47.5)$ & $6(7.5)$ & $4(5.0)$ & 0 \\
\hline County achieves reduced transportation costs & $44(55.0)$ & $32(40.0)$ & $2(2.5)$ & $2(2.5)$ & 0 \\
\hline County has reduced the quantity of goods that expire before usage & $48(60.0)$ & $30(37.5)$ & $2(2.5)$ & 0 & 0 \\
\hline County enjoys improved supplier adherence to expiration date requirements & $22(27.5)$ & $48(60.0)$ & $10(12.5)$ & 0 & 0 \\
\hline County gets and gives transparent price information & $6(7.5)$ & $53(66.3)$ & $21(26.3)$ & 0 & 0 \\
\hline County enjoys improved supplier adherence to delivery dates & $44(55.0)$ & $32(40.0)$ & $2(2.5)$ & $2(2.5)$ & 0 \\
\hline County has adequate staff trained per annum & $38(47.5)$ & $40(50.0)$ & $2(2.5)$ & 0 & 0 \\
\hline County implementation timely and appropriate planning & $32(40.0)$ & $38(47.5)$ & $6(7.5)$ & $4(5.0)$ & 0 \\
\hline
\end{tabular}

\subsection{E-Sourcing, E-Maintenance and Procurement Performance}

Correlation analysis was conducted to establish the relationship between E-Sourcing, E-Maintenance and Procurement Performance

The results were as presented in table 4 .

Table 5. E-Sourcing, E-Maintenance and Procurement Performance.

\begin{tabular}{llll}
\hline & & E-Sourcing & E-Maintenance \\
\hline Procurement & Pearson Correlation & $.497^{*}$ & $.405^{*}$ \\
Performance & Sig. (2-tailed) & .000 & .000 \\
& $\mathrm{~N}$ & 80 & 80 \\
\hline
\end{tabular}

The results of correlation analysis reveal that there was a significant association between E-Maintenance, Repair and Operations and the Procurement Performance of county governments in Kenya. Correlation results gave $r=0.497$, $\mathrm{p}=0.000(<0.05)$ indicating that e-sourcing has significant positive relationship procurement performance. This led to confirming that e-sourcing is a determinant of procurement performance and recommendation that e-sourcing activities should be adopted to achieve realistic progress in procurement performance. Similarly, The correlation results; $\mathrm{r}=0.405, \quad \mathrm{p}=0.000 \quad(<0.05)$ reveal significant positive correlation between e-maintenance and procurement performance.

The study revealed that there was also a strong association between E- Sourcing and Procurement Performance of county governments in Kenya implying that E-sourcing is critical to establishing a wider supplier base which can subsequently reduce some of the risks in the supply chain associated with disruption On e-maintenance, it was evident that usage of e-maintenance has made it possible to timely contact firms providing repair services and this had resulted in reduced stoppage in service delivery. E-Maintenance, Repair and Operations was found to be significant to the Procurement Performance of county governments in Kenya confirming that it was important to carry out E-Maintenance, Repair and Operations if there was to be a realistic progress in procurement performance.

From findings, the following recommendations are made; E-sourcing need to be done at every procurement cycle and databases be created on online suppliers in order to make them more traceable. The organization should recruit its own e-maintenance personnel in order to ensure the eprocurement system is fully functional and serviceable as required at all times.

\section{References}

[1] Andreanne, L. a. (2007). Innovation Theories: Relevance and Implications for Developing Country Innovation Discussion Paper 743.

[2] Barahona, J. C. (2012). The Disruptive Innovation Theory Applied to National Implementations of E-procurement. Electronic Journal of e-Government, (10)2.

[3] Brazel, J. F., \& Dang, L. (2008). The Effect of ERP System Implementations on the Management of Earnings and Earnings Release Dates. Journal of Information Systems, 121.

[4] Group, A. (2001). Best Practices in E-Procurement: The Abridged Report of December. Aberdeen Group.

[5] Group, A. (2005). Best Practices in E-Procurement. Reducing Costs and Increasing Value through Online Buying. Best Practices in E-Procurement. Aberdeen Group.

[6] Hoon Hah, F. (2006). Critical Success Factors For Enterprise Resource Planning Implementation and Upgrade. Journal of Computer Information Systems, 77-113.

[7] Humble E. J., H. R. (2003). Enterprise Resource PlanningImplememtation Procedure and Critical Sucess Factors. European Journal of Operations Research, 241-257.

[8] Innovation, C. C. (2006). E-Tendering - Security and Legal Issues. Office Cooperative Research Centre for Construction Innovation.

[9] Jeppesen, R. (2010). Accountability in Public Procurement transparency and the role of civil society. UNDP.

[10] K, S. (2010). E-Procurement in Tanzania. 3rd East Africa Procurement Forum-White Sands Hotel, Dar es Salaam, 29th1 st Sept.

[11] Kaliannan, M. A. (2009). Government Purchasing: A Review of E Procurement System in Malaysia. The Journal of Knowledge Economy \& Knowledge Management, 123-134.

[12] Kothari, C. (2004). Research Methodology-Methods and Techniques. New Delhi:New Age International (P) Limited Publishers. 
[13] Lestikow, G. (2009). Procurement in Brazil: Electronic Procurement as Anti-corruption Reform. The Journal Of International Policy Solutions., 10 1-14.

[14] Lewis, D. M. (2004). Essentials of e-Sourcing: A Practical Guide for Managing the RFX Process. In An "E" Environment 89th Annual International Supply Management Conference.

[15] Mbwesa, J. (2006). Introduction to Management Research: A Student Handbook,. Nairobi: Basic Modern Management consultants.

[16] Mose, M. J. (2013). The Critical Success Factors and Challenges in E-procurement Adoption among Large Scale Manufacturing Firms in Nairobi, Kenya. European Scientific Journa. 9-13.

[17] Mugenda, O. \&. (2003). Research Methods; Quantitative and Qualitative Approaches. Nairobi Kenya.: Africa Centre of Technology (ACTS).

[18] Muma, B. O. (2014). Green Supply Chain Management and Environmental Performance among Tea Processing Firms in Kericho County, Kenya. International Journal of Economics, Finance and Management Science, 2(5).

[19] Nah, F. F. (2004). Critical Success Factors for ERP Implementation. Best Practice Network.

[20] Nah, F. F. (2006). Critical Success Factors for E-Sourcing: A Enterprise Resource Planning Implementation and Upgrade. Best Practice Network. Buy IT E-Procurement Best Practice Guideline Special Issue 2006.

[21] OGC. (2014, October 14th). Implementing E-Tendering.

[22] Oileary, E. D. (2004). Entreprise Resource Planning SystemsAn Empirical Analysis of Benefits. Journal of Emerging Technologies, 63-72.

[23] Oyugi T. and Maina, K. (2004). Relationship between human characteristics and adoption of project management information system in non-governmental organizations' projects in Nakuru Town (Kenya). International Journal of Intelligent Information System, 123-134.
[24] Reddick, C. G. (2004). The Growth of E-Procurement in American State Governments: A Model and Empirical Evidence. Journal of Public Procurement, 4(2) 151-176.

[25] Rogers, E. M. (2014). Diffusion of Innovations Theory. Retrieved February 11th, 2015, from http://www.tcw.utwente.nl/theorieenoverzicht/Theory\%20clus ters/Communication\%20ad\%20Information\%20Technology/ Diffusion_of_Innovations_Theory.doc/.

[26] Saunders, M. L. (2012). Research Methods for Business Students. Italy: Pearson Education ltd.

[27] She, W. a. (2007). Security for Enterprise Resource Planning Systems. Information Systems Security, 16: 152-163.

[28] Shirzad, S. R. (2012). A Systematic Literature Review of Flexible E-Procurement Marketplace. Journal of Theoretical and Applied Electronic Commerce Research, 8(2) 49-70.

[29] Snow, J. (2013). Procurement Performance Indicators Guide using Procurement Performance Indicators to Strengthen the Procurement Process for Oublic Health Commodities. US: Agency for International Development.

[30] United Nations. (2011). E-Procurement Towards Transparency and Effeciency in Public Service Delivery. New York: United Nations.

[31] United States International Agency. (2008). Intergrated Financial Management Information System. Retrieved February 20th, 2015, from United States International Agency: www.usaid,gov.

[32] Vaidya, A. S. (2006). Critical Factors that Influence EProcurement Implementation Success in the Public Sector. Journal of Public Procurement, 20-99.

[33] Works, C. K. (2006, October 14th). Successful E-Tendering.

[34] Yossuf, S. W. (2011). Electronic Government Procurement Adoption Behaviour amongest Malaysisn SMEs. International Business Research, 100-111. 